\title{
Study of Biochemical and Yield Traits with Different Growth Retardants in Cowpea cv. Kashi Kanchana
}

\author{
V. Madhu Suman* and Suchit A. John \\ Department of Biological Sciences, Sam Higginbottom University of Agriculture, Technology \\ and Sciences, Allahabad (U.P.), India \\ *Corresponding author
}

\section{A B S T R A C T}

\begin{tabular}{|c|}
\hline Keywords \\
\hline $\begin{array}{l}\text { Maleic hydrazide, } \\
\text { Lichocin, Cycocil, } \\
\text { Chlorophyll content } \\
\text { and Seed yield }\end{array}$ \\
\hline Article Info \\
\hline $\begin{array}{l}\text { Accepted: } \\
28 \text { January } 2018 \\
\text { Available Online: } \\
10 \text { February } 2018\end{array}$ \\
\hline
\end{tabular}

A field experiment was conducted to know the effect of growth retardants viz, Maliec hydrazide (MH), Cycocil (CCC) and Lichocin on growth characters, seed quality, yield and yield components in cowpea during the Rabi season 2016-17. The experiment was laid out in RBD with three replications. Results revealed that the application of growth retardant reduced the plant height. The minimum plant height was recorded in $\mathrm{MH}$ (500 ppm). The chlorophyll content was differed significantly at 60days it was highest in Lichocin $(500 \mathrm{ppm})$ followed by CCC $(1000 \mathrm{ppm})$. In the entire treatments crop growth rate were increased over control and was highest in Lichocin (1000 ppm). At 90 days after sowing relative growth rate was significantly more in CCC (500 ppm). The yield contributing characters viz, seed yield per plant, number of pods per plant, seed per pod, seed index and seed yield $\left(\mathrm{g} \mathrm{m}^{-2}\right)$ increased significantly due to growth retardants. Among the treatments Lichocin $(1000 \mathrm{ppm})$ recorded significantly higher seed yield than other treatments.

\section{Introduction}

The largest production of cowpea is with over 4.3 million metric tons of annual production while the grain is a good source of human protein while the haulms are valuable source of livestock protein. It is also source of income from many small holder farmers and contributes to the sustainability of cropping system and soil fertility improvement in marginal land through provision of ground cover by plant residue and nitrogen fixation. All part of cowpea is useful for food and is nutritious, providing protein, vitamin and mineral. The protein in cowpea seed is richer in amino acid, lysine and others compared to cereal grain (Anon., 2015) the cowpea haulm is also great value to farmers it is also use as cover crop, green manure crop, used for feeding animals and also for soil erosion control. Weeds serve as the main constraint to its production which resulted in low yield, poor quality of the crop and also low income to the farmer.

Pulses occupy an indispensable place in our daily diet as a source of protein. India is a major pulse growing country in the world occupying an area of $43.45 \mathrm{~m} \mathrm{ha}^{-1}$ producing $17.24 \mathrm{~m}$ tons with an average productivity of 
$660 \mathrm{~kg} \mathrm{ha}^{-1}$ (Anon., 2015). Cowpea (Vigna unguiculata (L). Walp.) is valuable warm season grain legume in tropical and subtropical zones of Africa, Asia and U.S.A it is widely adopted and capable of producing seeds even in lowland and semi-arid regions. However, grain yield of this legume varies widely when grown at different locations.

For normal growth and development hormones like, auxins, gibberellins, ethylene, cytokinin and abscisic acid are required in proper proportions and any imbalance leads to the shedding of reproductive organs.

One of the reasons for low productivity of this crop is due to its large scale cultivation under rainfed and low input conditions coupled with non-availability of high yielding varieties. The crop also produces excessive vegetative growth in heavy rain fall areas and under irrigated conditions resulting in to poor yield. The physiological reasons for variation in productivity may be attributed to poor sourcesink relationship, poor translocation efficiency at later stages crop growth, shedding of floral parts and low harvest index. (Manivannan et al., 2011)

\section{Materials and Methods}

Field experiment were conducted at the Central Experimental field, Sam Higginbottom, University of Agriculture, Technology and Sciences, during the Rabi season of 2016-17 to evaluate the growth retardant in biochemical and yield traits in Kashi Kanchana varitey of cowpea. The site selected was uniform, cultivable with typical sandy loam soil having good drainage. All the package of practices was followed as per the general agronomic practices for Cowpea crop. Five randomly selected plants were tagged from each treatment for recording the observations on bio chemical and yield. Observations viz, number of seed per plant, cholorophyll and seed protein was recorded as per the standard procedures are as follows.

Estimation of chlorophyll content: The chlorophyll content was measured by following the method of Arnon, (1949). Seed Protein content was estimated by the method of Lowry et al., (1951) by using BSA as standard protein.

\section{Results and Discussion}

The yield and yield attributes viz, number of seeds per pod, seed per plant seed index seed per $\mathrm{m}^{-2}$ were differed significantly by the application of growth retardant. Among the treatments, lichocin $1000 \mathrm{ppm}$ was recorded significantly higher seeds per pod (14.40), seed index (14.10), seed yield per plant (30.6 g) and seed weight per $\mathrm{m}^{-2}\left(460 \mathrm{~g}^{-1}\right)$ and lowest number of pods per plant and seeds per pod (13.0) was observed in maleic hydrazide $500 \mathrm{ppm}$ and maleic hydrazide $250 \mathrm{ppm}$ (10.8), respectively. Lowest seed yield per plant and seed yield per meter row length was observed in maleic hydrazide $250 \mathrm{ppm}$ and in maleic hydrazide $500 \mathrm{ppm}$ (17.4 and 29.2, respectively). Similar results were observed by Vanangamudi et al., (2003). The data on total chlorophyll recorded at 30 DAS no significant differences were observed for chlorophyll content. However, at 60 DAS significantly higher cholorophyll content (2.90) was obtained lichocin $500 \mathrm{ppm}$ and lower cholorophyll CCC $500 \mathrm{ppm}$ (2.40) at 90 DAS significantly higher chlorophyll content (2.40) was maleic hydrazide and lower cholorophyll (1.50) lichocin $500 \mathrm{ppm}$. The maximum total chlorophyll contents were recorded in lichocin $500 \mathrm{ppm}$ indicated that these chemical are effective in inducing chlorophyll synthesis compared to other chemicals. Sawan et al., (2007) also reported that the application of lichocin significantly increased total cholorophyll as similar to control in sunflower. 
Table.1 Effect of growth retardants on chlorophyll content and seed protein parameters of cowpea

\begin{tabular}{|c|c|c|c|c|c|}
\hline \multirow{2}{*}{\multicolumn{2}{|c|}{ Treatments }} & \multicolumn{3}{|c|}{ Cholorophyll content (mg/g) } & \multirow{2}{*}{$\begin{array}{l}\text { Seed Protein } \\
\text { content }(\%)\end{array}$} \\
\hline & & 30 DAS & 60 DAS & 90 DAS & \\
\hline$\overline{T_{0}}$ & Control & 3.9 & 1.9 & 0.7 & 21.7 \\
\hline$\overline{T_{1}}$ & $\begin{array}{l}\text { Maleic hydrazide } \\
(250 \mathrm{ppm})\end{array}$ & 3.8 & 2.5 & 2.7 & 22.6 \\
\hline$\overline{T_{2}}$ & $\begin{array}{l}\text { Maleic hydrazide } \\
(500 \mathrm{ppm})\end{array}$ & 3.0 & 2.8 & 2.4 & 23.1 \\
\hline$\overline{T_{3}}$ & $\begin{array}{l}\text { CCC (chloro choline } \\
\text { chloride) }(500 \mathrm{ppm})\end{array}$ & 3.6 & 2.4 & 1.6 & 21.9 \\
\hline$\overline{T_{4}}$ & $\begin{array}{l}\text { CCC (chloro choline } \\
\text { chloride) (1000ppm) }\end{array}$ & 2.6 & 2.7 & 1.9 & 22.4 \\
\hline$\overline{T_{5}}$ & Lichocin (500ppm) & 3.8 & 2.9 & 1.5 & 22.0 \\
\hline$\overline{T_{6}}$ & Lichocin (1000ppm) & 3.5 & 2.7 & 1.8 & 21.9 \\
\hline & Mean & 3.40 & 2.40 & 0.99 & 22.1 \\
\hline & SEm \pm & 0.60 & 0.10 & 0.06 & 0.34 \\
\hline & C. D. $(5 \%)$ & NS & 0.36 & 0.20 & NS \\
\hline
\end{tabular}

Table.2 Effect of growth retardants on yield and yield parameters of cowpea

\begin{tabular}{|c|c|c|c|c|c|c|}
\hline \multicolumn{2}{|r|}{ Treatments } & $\begin{array}{c}\text { Number of } \\
\text { pods }\end{array}$ & $\begin{array}{l}\text { Number of } \\
\text { seed per pod }\end{array}$ & $\begin{array}{l}\text { Seed } \\
\text { index }\end{array}$ & $\begin{array}{c}\text { See yield } \\
\left(\mathrm{g} \text { plant } \mathrm{t}^{-1}\right)\end{array}$ & $\begin{array}{c}\text { Seed yield } \\
\left(\mathrm{g} \mathrm{m}^{-2}\right)\end{array}$ \\
\hline $\mathrm{T}_{0}$ & Control & 13.00 & 10.10 & 12.20 & 16.20 & 244 \\
\hline$T_{1}$ & $\begin{array}{l}\text { Maleic hydrazide } \\
(250 \mathrm{ppm})\end{array}$ & 13.20 & 10.80 & 12.20 & 17.40 & 292 \\
\hline $\mathrm{T}_{2}$ & $\begin{array}{l}\text { Maleic hydrazide } \\
(500 \mathrm{ppm})\end{array}$ & 13.00 & 12.10 & 12.10 & 19.40 & 334 \\
\hline$T_{3}$ & CCC (500ppm) & 13.50 & 12.50 & 13.10 & 22.20 & 308 \\
\hline $\mathrm{T}_{4}$ & CCC (1000ppm) & 13.20 & 11.60 & 13.20 & 20.50 & 364 \\
\hline$T_{5}$ & Lichocin (500ppm) & 14.50 & 13.30 & 12.40 & 24.20 & 262 \\
\hline $\mathrm{T}_{6}$ & $\begin{array}{l}\text { Lichocin } \\
\text { (1000ppm) }\end{array}$ & 14.90 & 14.40 & 14.10 & 30.60 & 460 \\
\hline & Mean & 13.6 & 12.1 & 12.8 & 21.5 & 323 \\
\hline & S.Em. \pm & 0.50 & 0.24 & 0.13 & 0.74 & 11.0 \\
\hline & C. D. $(5 \%)$ & 1.10 & 0.53 & 0.27 & 1.60 & 24.0 \\
\hline
\end{tabular}

There is increase in protein content in all the treatments as compared to control, no significant differences among the treatments were noticed, similarly Nagurjana et al., (1999) observed that, $\mathrm{MH}$ had no effect on seed protein content in ground nut whereas,
MH significantly increased the seed oil content. Hunje et al., (1991) has also reported that the growth regulators viz, TIBA, CCC and $\mathrm{MH}$ did not show significant difference in seed protein content. Growth retardants are caused to inhibition of cell division and 
initiated the development of chloroplast, as a result plants treated with growth retardants has much dark green leaves than those untreated plants, it was observed in the present study that there was an increase total chlorophyll due to application of growth reatardants.

It is concluded that the application of plant growth retardants decreases the growth by alter the plant architecture appears to be an excellent tool. The effects of growth retardants vary with the plant species, variety, concentration used, frequency of application and various other factors which influence the uptake and translocation of the chemical. Moreover, growth retardants play a significant role in modifying morphology, physiology and reproductive phase of cowpea. It was observed in the present investigation that the application of growth retardants significantly increased the number of pods, number seed per pod, seed index, which are the important yield determining components in cowpea, among various treatments imposed. The per cent increase in the yield was more with lichocin 1000 ppm followed by lichocin $500 \mathrm{ppm}$ and CCC 1000 ppm as compared to control. To achieve optimum vegetative growth and to effect better translocation of photosynthates in developing pods, the use of growth retardants which regulate plant growth and finally alter the plant architecture and yield improvement appears to be an excellent tool.

\section{References}

Albacete, A. A., Martínez-Andújar, C., Pascual, J. A., Acosta, M. and PérezAlfocea, F., 2008, Increasing vegetative growth, yield and seed quantity in tomato by inducing plant vigour at the earliest seedling stage. Acta Horticulturae, 30(7): 265-271.
Anonymous, 2015, Ministry of Agriculture, Government of India.

Arnon, D. I., 1949, copper enzymes in isolated chloroplasts, polyphenoxidase in beta vulgaris. Plant physiology, 24: 1-15.

Carvalho, M. E. A., De Camargo Castro, P. R., De Castro Ferraz, M. V. and Mendes, A. C. C. M., 2016, are plant growth retardants a strategy to decrease lodging and increase yield of sunflower. Comunicata Scientiae, 7(1): 154-159.

Hunje, R. V., Vyakaranahal, B. S., Kulkarni, G. N. and Shashidhara, S. D., 1991, Effect of growth regulators on seed quality of vegetable cowpea. Curr. Res., 20(2): 236-237.

Kumar, V., Vyakarnahal, B. S., Basavaraj, N. and Birbal, 2010, Effect of growth retardants and methods of application on growth and yield of potato. Indian Journal of Horticulture, 67(9): 308-313. Lone, N. A., Khan, N. A., Bhat, M. A., Mir, M. R., Razvi, S.M., Baht, K. A. and Rather, G. H, 2010,International Journal of Current Research, 6(1):001007.

Lowry, O. H., Rosebrough, N. J., Farr, A. L., and Randall, R. J., 1951, Total protein estimation by Lowry's method. J. Biol. Chem., 193: 265.

Manivannan Khan, A. L., Won, J. G. and Lee, I.J., 2011, Influence of prohexadionecalcium, trinexapac-ethyl and hexaconazole on lodging characteristic and gibberellin biosynthesis of rice (Oryza sativa L.). African Journal of Biotechnology, 10(61):13097-13106.

Nagarjun, P., Radder, G. D. and Patil, V. S., 1999, Effect of foliar application of maleic hydrazide on seed quality and seedling vigour in bunch groundnut. Seed Res., 8(1): 121-126.

Oswalt, J. S., Rieff, J. M., Severino, L. S., Bednarz, C. W. and Ritchie, G. L.,2014, Plant height and seed yield of castor 
(Ricinus communis L.) sprayed with growth retardants and harvest aid chemicals. Industrial Crops and Products, 6(1): 272-277.

Rademacher, W., 2000, Growth retardants: Effects on gibberellin biosynthesis and other metabolic pathways. Annual Review of Plant Biology, 51(1): 501531.

Reddy, B. T., Ninganur, M. B., Chetti and Hiremath, S. M., 2009 Karnataka J. Agric. Sci., 22(2):289-292.
Sawan Z. M., Hafez, S. A., Basyony, A. E., and Alkassas, A. R., 2009, Grasays y aceites, Julio sep, 58(3):0017-3475.

Vanangamudi, K., Srimathi, P., Natarajan, N. and Bhaskaran, M., 2003, Current scenario of seed coating polymer. ICAR - Short course on seed hardening and pelleting technologies for rain fed or garden Land Ecosystems: 80-100.

\section{How to cite this article:}

Madhu Suman V. and Suchit A. John. 2018. Study of Biochemical and Yield Traits with Different Growth Retardants in Cowpea cv. Kashi Kanchana. Int.J.Curr.Microbiol.App.Sci. 7(02): 3789-3793. doi: https://doi.org/10.20546/ijcmas.2018.702.448 